\title{
Mycoplasma citelli, a New Species from Ground Squirrels
}

\author{
D. L. ROSE, ${ }^{1}$ J. G. TULLY, ${ }^{1}$ AND E. V. LANGFORD ${ }^{2}$ \\ Laboratory of Infectious Diseases, National Institute of Allergy and Infectious Diseases, Bethesda, \\ Maryland 20014, ${ }^{1}$ and Animal Pathology Division, Agriculture Canada, Animal Diseases Research Institute
} (Western), Lethbridge, Alberta, Canada T1J $3 Z 4^{2}$

\begin{abstract}
Two mycoplasmas, from a group of five strains previously recovered from ground squirrels, were found to be similar in biochemical and serological properties. The organisms were able to ferment glucose and other carbohydrates, did not hydrolyze arginine or urea, produced a film-and-spot reaction, and could grow at temperatures from 30 to $37^{\circ} \mathrm{C}$. The organisms required cholesterol for growth. The two strains were shown to be serologically distinct from 64 Mycoplasma species or unclassified serotypes. On the basis of these findings and of other morphological, biological, and serological properties of the organisms, it is proposed that mycoplasmas with these characteristics belong to a new species, Mycoplasma citelli. Strain RG-2C (= ATCC 29760) is the type strain.
\end{abstract}

The normal mycoplasma flora of most domestic animals is becoming fairly well documented. In contrast, the occurrence of mycoplasmas in wild or freshly captured animals is not well known. Mycoplasmas have been recovered from several wild and captive members of the Felidae $(10,13)$, from a number of freshly captured nonhuman primates $(3,5,11)$, and from several types of wild birds $(2,12)$. The occurrence of mycoplasmas in bighorn sheep (24), chamois (15, 17), and insectivorus hedgehogs (20) have also been recorded. Although many of the mycoplasmas recovered in these studies were not identified as to species, it is notable that, where biochemical and serological characterizations were performed, most of the isolates turned out to be Mycoplasma or Acholeplasma species previously known to occur in humans or domestic animals.

The recent discovery of new mycoplasmas in plant and insects has added important information to the distribution and habitat of these organisms. Our knowledge of the unique mycoplasma flora of animals in the wild can contribute not only to a more complete understanding of the ecology of this microbial group, but also to how humans interact with all mycoplasmas in the environment.

In this report, we present the characteristics of a group of mycoplasmas recovered earlier from ground squirrels (14). On the basis of their distinct biological and serological properties, we hereby offer a proposal that these organisms be given taxonomic status as a new Mycoplasma species.

\section{MATERIALS AND METHODS}

Mycoplasma strains. Details of the primary isolation of mycoplasmas from two ground squirrels ( $\mathrm{C} i$ - tellus richardsonii richardsonii) have been given previously (14). Two strains (RG-2C and RG-1D) of the five initial isolates were selected for further characterization, since a preliminary analysis of the biological and serological properties of the five strains suggested they were all interrelated (14). The reference strains used in this study for serological and biological comparisons with RG-2C and RG- $1 \mathrm{D}$ were stock cultures of mycoplasmas maintained in the Mycoplasma Section of the Laboratory of Infectious Diseases, Bethesda, Md.

Media and cultivation procedures. The isolates were grown on conventional mycoplasma broth, utilizing 70\% mycoplasma broth base (BBL Microbiology Systems, Cockeysville, Md.), $10 \%$ of a fresh $25 \%$ yeast extract (Microbiological Associates, Bethesda, Md.), and either $20 \%$ horse serum (Flow Laboratories, Rockville, Md.) or $1 \%$ bovine serum fraction (Difco Laboratories, Detroit, Mich.). The medium was also supplemented with $0.5 \%$ glucose, $0.2 \% \mathrm{~L}$-arginine hydrochloride, $0.002 \%$ phenol red, and $500 \mathrm{U}$ of penicillin per ml. A solid medium was prepared by adding $0.6 \%$ Noble agar (Difco) to the broth base before heat sterilization. Agar cultures were grown anaerobically (in an atmosphere of $95 \%$ nitrogen plus 5\% carbon dioxide). Although most cultures were maintained at $37^{\circ} \mathrm{C}$, selective broth and agar passages of the organisms were subjected to temperatures of 25 to $37^{\circ} \mathrm{C}$. The two strains under study (RG-2C and RG-1D) were purified by a $3 \times$ filtration-cloning procedure. This involved passage of a broth culture through a filter with an average pore diameter of $220 \mathrm{~nm}$, plating appropriate dilutions of the filtrate to agar plates, selecting single colonies from the resulting growth on agar, and reinoculation of broth tubes; the procedure was repeated twice more.

Mycoplasma broth media, similar to that noted above but devoid of penicillin or other antibiotics, were used to detect possible reversion of the RG-2C and RG-1D strains to bacteria. At least five passages on antibiotic-free medium were performed, and the cultures were spread on blood agar plates at each broth passage. Agar plates were incubated at $37^{\circ} \mathrm{C}$ and examined for bacterial colonies. 
Morphology. Broth cultures of the organism were examined under dark-field microscopy. Cells collected from liquid cultures were stained by the Gram technique and examined by light microscopy. An ultrastructural study was performed on cells collected by centrifugation of broth cultures $(12,000 \times g$ for 20 $\mathrm{min}$ ). Pellets were fixed and sectioned for examination by electron microscopy with procedures previously stated (6).

Fistration studies. A 48-h-old broth culture of strain RG-2C was examined for passage through a series of membrane filters with graded pore diameters (450-, 300-, and $220-\mathrm{nm}$ average pore diameters) by techniques outlined earlier (21).

Tests for biological and biochemical properties. The procedures used to determine carbohydrate fermentation, arginine and urea hydrolysis, phosphatase activity, tetrazolium reduction, serum or gelatin digestion, and film-and-spot reaction have been described earlier $(1,23)$. Most of these tests were performed on a broth medium containing $1 \%$ bovine se- rum fraction rather than on a medium with $20 \%$ horse serum. Susceptibility of the mycoplasmas to digitonin was assayed by a plate method, utilizing mycoplasma agar containing $20 \%$ horse serum (9). Hemadsorption of guinea pig erythrocytes to agar colonies of the two Mycoplasma strains was tested by a technique previously described (16).

Sterol requirement. Sterol requirements for the growth of strains RG-2C and RG-1D were determined by a broth culture method (19). A 5\% inoculum was employed, and the cultures were harvested after 5 days of incubation at $37^{\circ} \mathrm{C}$.

Serological tests. Hyperimmune antisera for serological testing were prepared to the mycoplasmas listed in Table 1. A portion of this collection represents antisera prepared as part of the National Institutes of Health mycoplasma reference reagent program (7). Methods of antiserum preparation for the remaining mycoplasmas have been outlined elsewhere (22).

Disk growth inhibition tests were performed with 24-h-old cultures of RG-2C and RG-1D grown on

TABLE 1. Mycoplasma strains and antisera used in serological tests

\begin{tabular}{|c|c|c|c|}
\hline Species and Strain & Source $^{a}$ & Species and Strain & Source $^{\alpha}$ \\
\hline Mycoplasma agalactiae (PG2) & NIH & M. molare (H542) . . & MS-LID \\
\hline M. alkalescens (D12) ........ & MS-LID & M. mycoides subsp. mycoides (B3) & MS-LID \\
\hline M. alvi (Ilsley) & MS-LID & M. mycoides subsp. capri (PG3) & MS-LID \\
\hline M. anatis (1340) & NIH & $M$. neurolyticum (type A) . . . & NIH \\
\hline M. arginini $(\mathrm{G} 230)$ & NIH & M. opalescens (MH5408) & MS-LID \\
\hline M. arthritidis (PG6) $\ldots$. & $\mathrm{NIH}$ & M. orale $(\mathrm{CH} 19299) \ldots$ & NIH \\
\hline M. bovigenitalium (PG11) & NIH & M. ovipneumoniae (ST93) & MS-LID \\
\hline M. bovirhinis (PG43) ... & $\mathrm{NIH}$ & M. pneumoniae (FH) & NIH \\
\hline M. bovis (Donetta) ... & MS-LID & M. primatum (HRC292) & MS-LID \\
\hline M. bovoculi (M165/69) & MS-LID & M. pulmonis (PG34) ... & NIH \\
\hline M. buccale (CH20247) & NIH & M. putrefaciens (KS-1) & MS-LID \\
\hline M. canis (PG14) ..... & NIH & M. salivarium (PG20) & NIH \\
\hline dense $(275 \mathrm{C}) \ldots$ & MS-LID & M. spumans ( $\mathrm{P}$ & NIH \\
\hline M. capricolum (California kid) & MS-LID & M. synoviae (W) & MS-LID ${ }^{b}$ \\
\hline M. caviae & MS-LID & M. verecundum & MS-LID \\
\hline M. conjunc & MS-LID & Mycoplasma sp. ( & MS-LID \\
\hline M. cynos & MS-LID & Mycoplasma sp. ( & MS-LID \\
\hline M. dispar & MS-LID & Mycoplasma sp. (bov & MS-LID \\
\hline M. edwardii (PG24) & MS-LID & Mycoplasma sp. (bo & MS-LID \\
\hline M. equirhinis (M432/72) & MS-LID & Mycoplasma sp. (bovine) $(70-159) \ldots \ldots$ & MS-LID \\
\hline M. faucium (DC333) .... & NIH & Mycoplasma sp. ( & MS-LID \\
\hline M. feliminutum (Ben) & MS-LID & group C) (CKK) & MS-LID \\
\hline M. felis (Cat 27) .... & MS-LID & group D) (SA-J) & MS-LID \\
\hline M. ferm & NIH & group F) (WR1) & MS-LID \\
\hline M. flocculare (Ms42) & MS-LID & Mycoplasma sp. (avian group I) (Iowa 695) & MS-LID \\
\hline M. gallinarum (PG16) & NIH & Mycoplasma sp. & MS-LID \\
\hline M. gallisepticum (PG31) & NIH & Acholeplasma ax & MS-LID \\
\hline M. gateat & MS-LID & A. equifetale (N93) $\ldots \ldots \ldots \ldots$ & MS-LID \\
\hline M. hominis (PG21) ... & NIH & A. granularum (BTS39) & NIH \\
\hline M. hyopneumoniae $(\mathrm{J})$ & MS-LID & A. hippikon (C1) ..... & MS-LID \\
\hline M. hyorhinis (BTS7) & NIH & A. laidlawii (PG8) & NIH \\
\hline M. hyosynoviae (S16) & MS-LID & A. modicum (PG49) & MS-LID \\
\hline$M$. iners (PG30) $\ldots$. & NIH & A. oculi (19L) ........ & MS-LID \\
\hline M. lipophilum (MaBy) & $\mathrm{NIH}$ & Acholeplasma sp. (S2) & MS-LID \\
\hline M. maculosum (PG15) & NIH & Spiroplasma citri (Maroc) . . . . . . . & MS-LID \\
\hline M. meleagridis (17529) & NIH & Spiroplasma sp. (corn stunt) (E-275) & MS-LID \\
\hline M. moatsii (MK405) . & MS-LID & Spiroplasma sp. (SMCA) . . . . . . . & MS-LID \\
\hline
\end{tabular}

${ }^{a}$ Abbreviations: NIH, National Institutes of Health (NIAID-NIH Research Reference Reagent); MS-LID, Mycoplasma Section, Laboratory of Infectious Diseases, National Institute of Allergy and Infectious Diseases.

${ }^{b} M$. synoviae conjugated antiserum only used in serological testing. 
either serum fraction or $20 \%$ horse serum broth (4). Antigens, which were usually used directly from broth or diluted 1:50 in culture medium, were tested against undiluted antiserum. The plate immunofluorescence (epi-FA) antibody test was performed by a direct method (8), utilizing mycoplasmas grown on agar. The colonies were stained with appropriate dilutions (usually $1: 5$ to $1: 20$ ) of fluorescein-conjugated antisera to mycoplasmas listed in Table 1.

Polyacrylamide gel electrophoresis. Mycoplasmas grown in broth ( $20 \%$ horse serum) were sedimented by centrifugation, the cell proteins were solubilized in phenol-acetic acid-water (2:1:0.5 $[\mathrm{wt} / \mathrm{vol} / \mathrm{vol}]$, and the extract was then tested in polyacrylamide gels containing $5 \mathrm{M}$ urea and $35 \%$ acetic acid $(18,22)$. Electrophoresis was carried out at a constant current of $5 \mathrm{~mA}$ per tube for a period of time necessary for a dye marker (rhodamine) to reach the lower end (cathode) of the tubes. Gels were stained for $10 \mathrm{~min}$ with $1 \%$ amido black in $7 \%$ acetic acid, rinsed in tap water, and de-stained by simple diffusion in $7.5 \%(\mathrm{vol} / \mathrm{vol})$ acetic acid.

\section{RESULTS}

A description of strains RG-2C and RG-1D follows.

Morphological and cultural properties. Broth cultures of strains RG-2C and RG-1D examined by dark-field microscopy showed nu- merous pleomorphic, round or coccobacillary forms, with few filaments apparent in cultures of young or old cells. Cells stained by the Gram technique revealed gram-negative polymorphic structures similar to those observed in dark-field preparations. Examination of thin sections of cell pellets by electron microscopy confirmed the frequent occurrence of round or oval cells 200 to $300 \mathrm{~nm}$ in diameter (Fig. 1). No cell wall material was visible outside of the unit membrane of the organism.

Broth cultures of RG-2C showed a light turbidity after 2 to 5 days of incubation, with growth on $20 \%$ horse serum media superior to that obtained in serum fraction broth. Although growth was not apparent in cultures maintained at $25^{\circ} \mathrm{C}$, both RG-2C and RG-1D grew at a temperature of $30^{\circ} \mathrm{C}$ for more than five passages. Enhanced growth of broth cultures occurred at $37^{\circ} \mathrm{C}$. Classical "fried-egg" colonies were observed on solid media (Fig. 2) after 2 to 5 days of incubation at $37^{\circ} \mathrm{C}$. Optimal growth on agar occurred when plates were incubated in an atmosphere of $95 \%$ nitrogen plus $5 \%$ carbon dioxide. Some variation in colony size was apparent in $3 \times$-cloned cultures of both strains under examination. These colonial variants were exam-

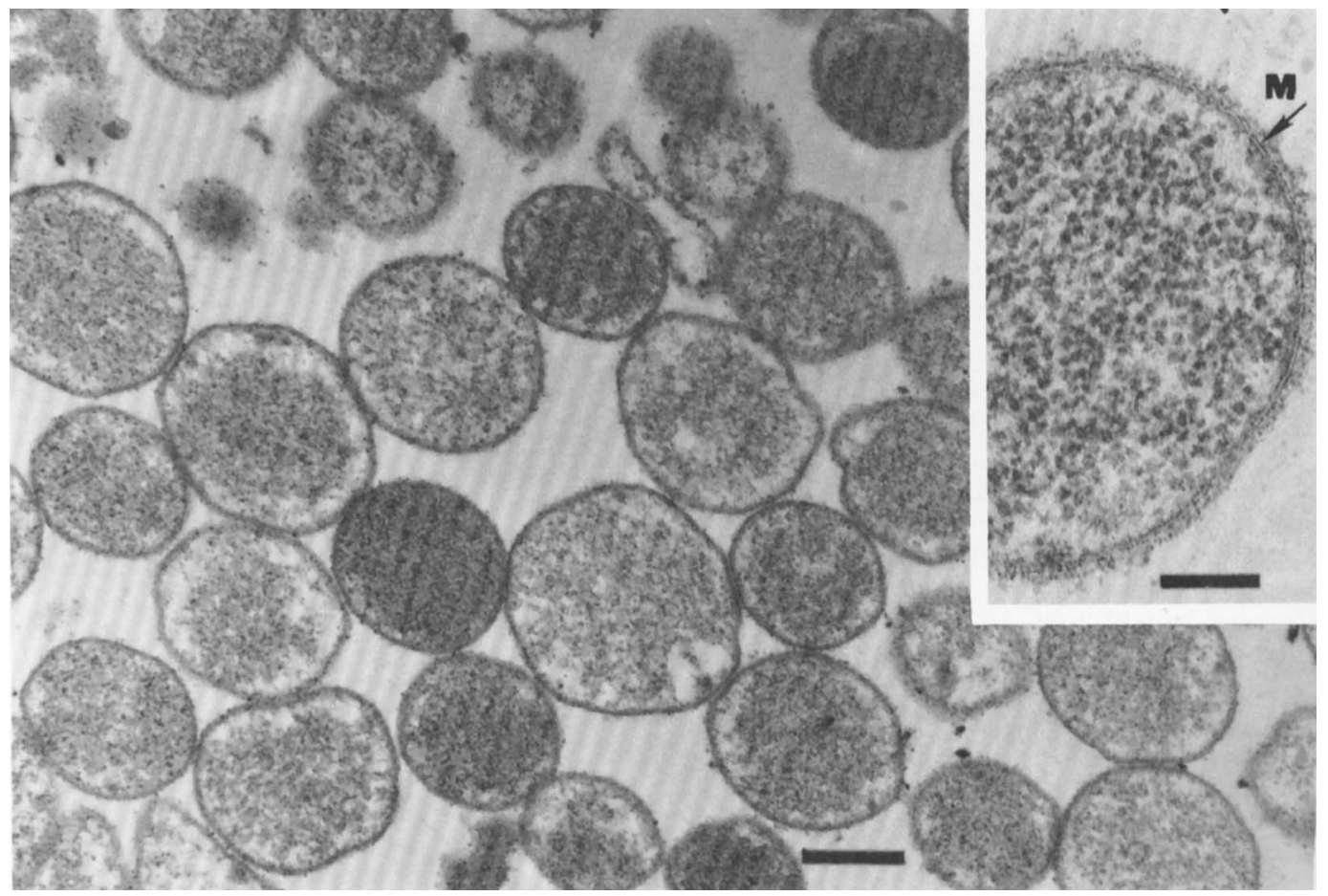

FIG. 1. Electron micrograph of strain RG-2C. Thin-section preparation of a 4-day-old culture stained with uranyl acetate. Bar represents $500 \mathrm{~nm}$. Inset: Higher magnification of cell, showing unit membrane (M). Bar represents $100 \mathrm{~nm}$. 


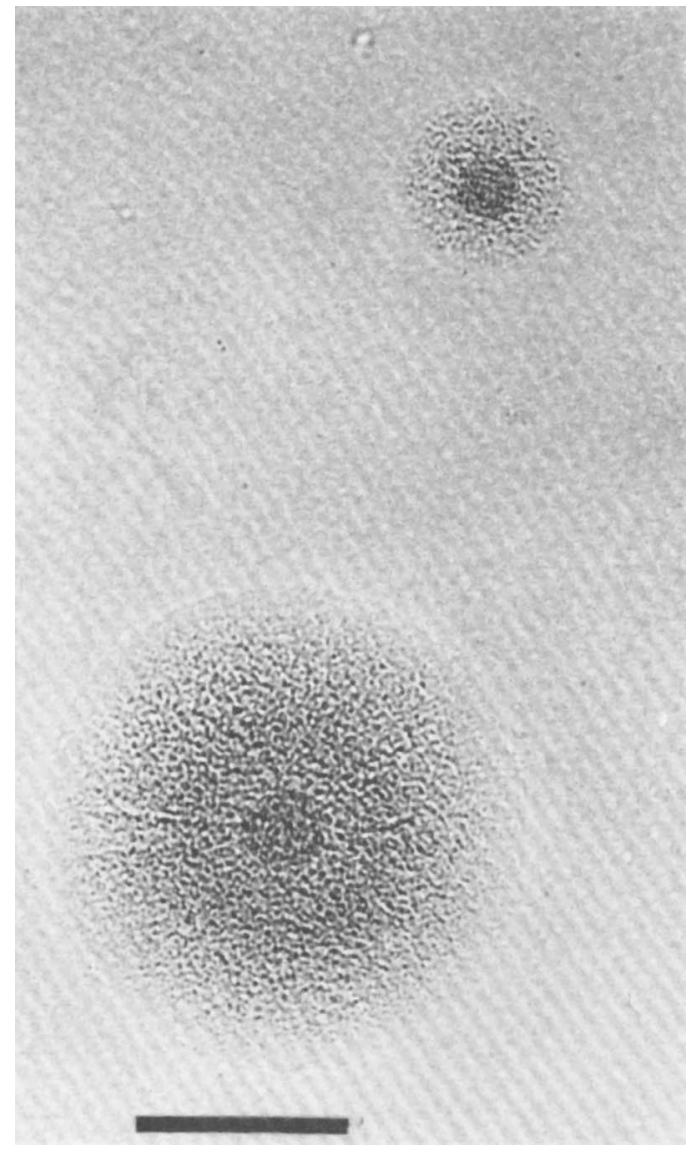

FIG. 2. Colonies of strain RG-2C (16th passage) on $20 \%$ horse serum agar after 3 days of incubation at $37^{\circ} \mathrm{C}$ in an atmosphere of $95 \% \mathrm{~N}$ plus $5 \% \mathrm{CO}_{2} . \mathrm{Bar}$ represents $100 \mu \mathrm{m}$.

ined extensively in serological tests (noted below), and it was concluded that they did not contain mixtures of other mycoplasmas but were completely interrelated serotypes. Also, colonial variants did not breed true, and mixtures of colony size were observed in cultures subjected to repeated filtration-cloning procedures.

Reversion studies. Cultures of the mycoplasmas maintained in antibiotic-free broth media for at least five passages exhibited growth characteristics similar to those observed when penicillin was present. There was no evidence of reversion to bacterial forms, either when gramstained cells from these cultures were examined or when platings were made to bacteriological agar.

Filtration studies. A cloned broth culture of RG-2C contained $4.47 \times 10^{6}$ colony-forming units per $\mathrm{ml}$ before filtration through a series of membrane filters. The numbers of colony form- ing units per milliliter after filtration through membrane filters of 450,300 , and $220 \mathrm{~nm}$ average pore diameters were $1.4 \times 10^{5}, 8.6 \times 10^{4}$, and 1.8 $\times 10^{2}$, respectively.

Biochemical and biological properties. The results of various biochemical tests performed on RG-2C and RG-1D, and other biological properties determined in this study, are summarized in Table 2. Both strains fermented glucose and other carbohydrates tested. The organisms also produced fairly strong film-andspot reactions on conventional mycoplasma agar media (containing $20 \%$ horse serum) after 7 days of incubation.

Sterol requirement. The growth response of RG-2C to cholesterol is shown in Table 3. Little growth was apparent in the absence of choles-

TABLE 2. Biochemical and biological characteristics of strains $R G-2 C$ and $R G-1 D$

\begin{tabular}{|c|c|}
\hline Property & Result \\
\hline $\begin{array}{c}\text { Fermentation of carbohy- } \\
\text { drates (glucose, mannose, } \\
\text { sucrose, fructose) } \ldots \ldots \ldots \ldots\end{array}$ & \\
\hline Hydrolysis of arginine $\ldots \ldots$ & - \\
\hline Hydrolysis of urea ..... & - \\
\hline Phosphatase production . . & + \\
\hline $\begin{array}{l}\text { Tetrazolium reduction (aero- } \\
\text { bic/anaerobic) } \ldots \ldots \ldots \ldots\end{array}$ & $\pm / \pm$ \\
\hline $\begin{array}{l}\text { Liquefaction of coagulated se- } \\
\operatorname{rum}(\ldots \ldots \ldots \ldots \ldots \ldots\end{array}$ & \\
\hline Film-and-spot reaction $\ldots \ldots$ & \\
\hline $\begin{array}{l}\text { Susceptibility to digitonin } \\
(1.5 \% \text { solution })\end{array}$ & $+(8 \mathrm{~mm})$ \\
\hline $\begin{array}{r}\text { Hemadsorption } \text { (guinea pig } \\
\text { erythrocytes) }\end{array}$ & \\
\hline $\begin{array}{l}\text { Sterol requirement } \ldots \ldots \ldots \ldots \\
\text { Culture turbidity } \ldots \ldots \ldots \ldots\end{array}$ & $\begin{array}{r}+ \\
\text { Light }\end{array}$ \\
\hline Colonies on agar ......... & $\begin{array}{l}\text { Medium to large ("fried } \\
\text { egg") }\end{array}$ \\
\hline Preferred atmosphere $\ldots$ & $\begin{array}{r}\text { Anaerobic }(95 \% \mathrm{~N}+5 \% \\
\left.\mathrm{CO}_{2}\right)\end{array}$ \\
\hline Preferred temperature & $37^{\circ} \mathrm{C}$ (growth at $30^{\circ} \mathrm{C}$ ) \\
\hline
\end{tabular}

TABLE 3. Effect of cholesterol on growth of strain $R G-2 C$ in serum-free medium

\begin{tabular}{cc}
\hline Cholesterol in medium $(\mu \mathrm{g} / \mathrm{ml})$ & Cell protein $^{a}$ \\
\hline $0^{b}$ & 0.20 \\
$0^{c}$ & 0.50 \\
1.0 & 0.20 \\
5.0 & 1.50 \\
10.0 & 3.50 \\
20.0 & 4.50 \\
Control $^{d}$ & 5.00 \\
\hline
\end{tabular}

${ }^{a}$ Expressed in milligrams of protein in cell pellets obtained from $100 \mathrm{ml}$ of medium.

${ }^{b}$ Serum-free medium alone.

'Serum-free medium with $0.5 \%$ albumin, $0.01 \%$ Tween 80 , and $10 \mu \mathrm{g}$ of palmitic acid per $\mathrm{ml}$.

${ }^{d}$ Medium containing $1 \%$ bovine serum fraction. 
terol, and the addition of cholesterol $(20 \mu \mathrm{g} / \mathrm{ml})$ resulted in amounts of growth similar to that obtained when organisms were grown in the serum fraction broth.

Serological tests. Growth inhibition and plate immunofluorescence tests, with antisera or conjugates prepared to the mycoplasmas listed in Table 1 , indicated that the ground squirrel mycoplasmas were serologically unrelated to previously described mycoplasmas, including both fermentative and nonfermentative $\mathrm{Myco}$ plasma and Acholeplasma species. As noted earlier, agar colony variations in cloned lines of both RG-2C and RG-1D strains prompted further serological tests on antisera prepared against individual large- and small-colony lines of the RG-2C line. The results of these comparisons (Table 4) indicated that the segregated colony lines were serologically related.

Polyacrylamide gel patterns. A comparison of the electrophoretic patterns of cell proteins from strains RG-2C and RG-1D in polyacrylamide gels is shown in Fig. 3. The patterns of the two strains are similar, whereas the general electrophoretic pattern of the organism appeared distinct from other cell protein patterns of Mycoplasma species retained in a collection in the National Institutes of Health laboratory.

\section{DISCUSSION}

A preliminary analysis of the biological and serological properties of ground squirrel mycoplasmas was noted earlier (14). More extensive evaluations presented here confirmed the earlier impressions that these organisms are serologically distinct from other members of species, subspecies, or unclassified serotypes of the order Mycoplasmatales. Their growth requirements for sterol and their morphology place the organisms in the family Mycoplasmataceae. An inability to hydrolyze urea indicates that the organisms should be assigned to the genus Myco-

TABLE 4. Growth inhibition (GI) and plate immunofluorescence (FA) tests with antisera and conjugates prepared to two colonial variants of strain $R G-2 C^{a}$

Test results with antiserum or conjugates prepared to:

\begin{tabular}{|c|c|c|c|c|}
\hline \multirow[t]{2}{*}{ Mycoplasma antigens } & \multicolumn{2}{|c|}{$\mathrm{RG}-2 \mathrm{C}(\mathrm{L})$} & \multicolumn{2}{|c|}{ RG-2C (S) } \\
\hline & $\mathrm{GI}^{b}$ & FA & $\mathrm{GI}^{b}$ & FA \\
\hline $\mathrm{RG}-2 \mathrm{C}(\mathrm{L})$ & 5 & $1: 256$ & 5 & $1: 32$ \\
\hline $\mathrm{RG}-2 \mathrm{C}(\mathrm{S})$ & 10 & $1: 256$ & 10 & $1: 32$ \\
\hline RG-1D (L) & 5 & $1: 256$ & 5 & $1: 32$ \\
\hline RG-1D (S) & 10 & $1: 256$ & 10 & $1: 32$ \\
\hline
\end{tabular}

${ }^{a} \mathrm{~L}$, Large colony; S, small colony.

${ }^{b}$ Millimeters.

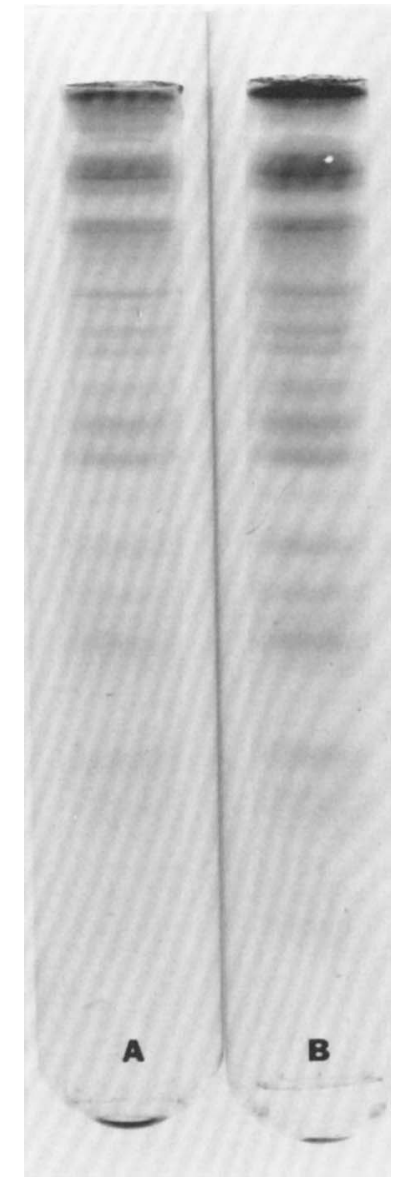

FiG. 3. Electrophoretic patterns of cell proteins of strains $R G-1 D(A)$ and $R G-2 C(B)$.

plasma. We believe that these organisms represent a new species within this genus and, therefore, propose the name Mycoplasma citelli for them (ci'tel.li. M.L. masc. noun Citellus a genus of ground squirrel; M.L. gen. noun citelli of Citellus). Strain RG-2C is the type strain. A cloned line of this strain has been deposited in the American Type Culture Collection (ATCC) under the number 29760.

\section{ACKNOWLEDGMENTS}

We thank R. M. Cole and T.J. Popkin for their generous assistance in the preparation, examination, and photography of specimens for electron microscopy. We also thank Colis Blood for his technical assistance.

\section{REPRINT REQUESTS}

Address reprint requests to: J. G. Tully, Mycoplasma Section, Laboratory of Infectious Diseases (7/200), National Institute of Allergy and Infectious Diseases, Bethesda, MD 20014. 


\section{LTERATURE CITED}

1. Aluotto, B. B., R. G. Wittler, C. O. Williamson, and J. E. Faber. 1970. Standardized bacteriologic techniques for the characterization of Mycoplasma species. Int. J. Syst. Bacteriol. 20:35-58.

2. Barber, T. L., and J. Fabricant. 1971. A suggested reclassification of avian mycoplasma serotypes. Avian Dis. 15:125-138.

3. Barile, M. F. 1973. Mycoplasmal flora of simians. J. Infect. Dis. 127 (Suppl.):17-20.

4. Clyde, W. A., Jr. 1964. Mycoplasma species identification based upon growth inhibition by specific antisera. J. Immunol. 92:958-965.

5. Cole, B. C., J. R. Ward, L. Golightly-Rowland, and C. E. Graham. 1970. Characterization of mycoplasmas isolated from great apes. Can. J. Microbiol. 16:1331-1339.

6. Cole, R. M., T. J. Popkin, R. J. Boylan, and N. H. Mendelson. 1970. Ultrastructure of a temperature-sensitive $\operatorname{Rod}^{-}$mutant of Bacillus subtilis. J. Bacteriol. 103: $793-810$.

7. Cunningham, S., and J. E. Nutter (ed.). 1975. NIAID catalog of research reagents, p. 849-949. Department of Health, Education and Welfare publication no. (NIH) 75-899. National Institutes of Health, Bethesda, Md.

8. Del Giudice, R. A., N. F. Robillard, and T. R. Carski. 1967. Immunofluorescence identification of Mycoplasma on agar by use of incident illumination. $\mathrm{J}$ Bacteriol. 93:1205-1209.

9. Freundt, E. A., B. E. Andrews, H. Ernø, M. Kunze, and F. T. Black. 1973. The sensitivity of Mycoplasmatales to sodium polyanethol-sulfonate and digitonin. Zentralbl. Bakteriol. Parasitenkd. Infektionskr. Hyg. Abt. 1 Orig. 225:104-112.

10. Hill, A. 1972. The isolation of Mycoplasma arginini from captive wild cats. Vet. Rec. 91:224-225.

11. Hill, A. 1977. The isolation of mycoplasmas from nonhuman primates. Vet. Rec. 101:117.

12. Jain, N. C., N. K. Chandiramani, and I. P. Singh. 1971. Studies on avian pleuro-pneumonia-like organisms. 2. Occurrence of mycoplasmas in wild birds.
Indiain J. Anim. Sci. 41:301-305.

13. Langford, E, V. 1974. Acholeplasma laidlawii and Pas teurella multicida isolated from the pneumonic lung of a lynx. J. Wildlife Dis. 10:420-422.

14. Langford, E. V. 1977. The recovery of a mycoplasma from Citellus richardsonii richardsonii (ground squirrel). Can. J. Comp. Med. 41:224-225.

15. Leach, R. H. 1970. The occurrence of Mycoplasma arginini in several animal hosts. Vet. Rec. 87:319-320.

16. Manchee, R. J., and D. Taylor-Robinson. 1968. Haemadsorption and hemagglutination by mycoplasmas. $J$. Gen. Microbiol. 50:465-478.

17. Nicolet, J., and E. A. Freundt. 1975. Isolation of $M y$ coplasma conjunctivae from chamois and sheep affected with kerato-conjunctivitis. Zentralbl. Veterinaermed Reihe B 22:302-307.

18. Razin, S. 1968. Mycoplasma taxonomy studied by electrophoresis of cell proteins. J. Bacteriol 96:687-694.

19. Rarin, S., and J. G. Tully. 1970. Cholesterol requirement of mycoplasmas J. Bacteriol. 102:306-310.

20. Tan, R. J. S., G. P. Davey, and J. M. B. Smith. 1971. A strain of Mycoplasma from the short-eared European hedgehog (Erinaceus europaeus). Res. Vet. Sci. 12:390-391.

21. Tully, J. G., M. F. Barile, R. A. Del Giudice, T. R. Carski, D. Armstrong, and S. Razin. 1970. Proposal for classifying strain PG-24 and related canine mycoplasmas as Mycoplasma edwardii sp. n. J. Bacteriol. 101:346-349.

22. Tully, J. G., M. F. Barile, D. G. ff. Edward, T. S. Theodore, and H. Ernø. 1974. Characterization of some caprine mycoplasmas, with proposals for new species, Mycoplasma capricolum and Mycoplasma putrefaciens. J. Gen. Microbiol. 85:102-120.

23. Williams, C. O., and R. G. Wittler. 1971. Hydrolysis of aesculin and phosphatase production by members of the order Mycoplasmatales which do not require sterol. Int. J. Syst. Bacteriol. 21:73-77.

24. Woolf, A., D. C. Kradel, and G. R. Bubash. 1970. Mycoplasma isolates from pneumonia in captive Rocky Mountain bighorn sheep. J. Wildlife Dis. 6:169-170. 